\title{
Accidental socialism: a natural experiment in Haiti 1796-1820
}

\author{
Mario Ferrero \\ Department of Humanities, University of Eastern Piedmont, Via G. Ferraris, 116, Vercelli, 13100, Italy \\ Corresponding author. Email: mario.ferrero@uniupo.it
}

(Received 2 July 2020; revised 2 October 2020; accepted 5 October 2020; first published online 4 November 2020)

\begin{abstract}
For some 25 years in revolutionary Haiti, most of the productive land was nationalized and run as state property. This paper shows that this economic system can be accurately described as agrarian socialism. Its life and death are compared with the experiences of 20th-century socialist regimes and their transition to a market economy, paying special attention to the kindred case of São Tomé. Haitian socialism is interesting because it was the unintended, accidental product of an emergency situation: the killing or flight of all the French landlords, which made their land vacant property and drove the state to run it in the public interest to defend the revolution. Therefore, it can be read as a natural experiment in socialism in the absence of a socialist ideology and of a socialist party that could hold the system together, constrain its income distribution, and control its eventual privatization.
\end{abstract}

Key words: Free-land hypothesis; Haitian revolution; privatization; property rights; socialism; state farms

JEL codes: P26; P32; P51

\section{Introduction}

For about a quarter of a century, during and after its struggle for independence, most of the productive land in Haiti was nationalized and run as state property. This paper argues that this economic system can be accurately described as agrarian socialism - a form of state agriculture that strikingly resembles later versions of state socialism. Though known to area historians, the phenomenon seems to have escaped the attention of scholars of comparative economic systems, political economy, and the economics of institutions. Yet, it is interesting because this socialist experiment happened not by design but by accident, as a consequence of the killing or flight of all the French landlords, which made their land vacant property and drove the state to try to run it in the public interest (as well as the private interest of its rulers). Therefore, the Haitian story can be read as a natural experiment in a socialist system in the absence of a socialist ideology and, most importantly, of a socialist party that could hold the system together, constrain its income distribution, and control its eventual privatization.

'Historical' natural experiments go beyond the narrow sense of econometric techniques to encompass any study in which a plausibly exogenous variation allows one to test the effect of a variable of interest - 'any historical imposition of a "treatment", evaluated relative to some counterfactual or control group' (Cantoni and Yuchtman, 2020: 8). Diamond and Robinson's (2010) collection also includes non-quantitative papers - in effect, case studies explicitly designed with this purpose in mind. In this paper, the sharp break in time and historical conditions, which precludes the possibility of a socialist ideology or party, is the 'treatment' imposed on the Haitian case relative to the control group of the

(C) Millennium Economics Ltd 2020. This is an Open Access article, distributed under the terms of the Creative Commons AttributionNonCommercial-NoDerivatives licence (http://creativecommons.org/licenses/by-nc-nd/4.0/), which permits non-commercial re-use, distribution, and reproduction in any medium, provided the original work is unaltered and is properly cited. The written permission of Cambridge University Press must be obtained for commercial re-use or in order to create a derivative work. 
20th-century socialist economies. As an added bonus, this treatment allows examination of an otherwise unheard-of case in comparative economic systems: a direct transition from slavery to socialism.

Our main sources in this paper will be a number of modern studies that summarize and use previous research: the classic study by Leyburn (1966), covering the entire period and beyond; three articles by the economic historian Lacerte (1975, 1978, 1981), based largely on official British, French, and Haitian government papers; and above all a series of studies by Lundahl (1979, 1984, 1985a, 1985b, 2013a, 2013b), covering the entire period of interest. The latter is the only economist to have applied to this material the tools of modern economic analysis. The traditional scholarly understanding of Haitian institutions, laid out by the near-contemporary observers Mackenzie (1830) and Lepelletier de Saint-Remy (1846), endorsed by Leyburn and followed by Lundahl, labels the systems of Toussaint, Dessalines, and Christophe as feudalism or serfdom, based on the fact that workers were bound to the plantation and plantations were entrusted to the management of big men answerable to the governor or the king. We will argue instead that a form of agrarian socialism, unintentional and avant la lettre, based on state ownership of land and state direction of agriculture, is a more insightful description - one that lends itself to comparison with the self-conscious systems bearing that name in the 20th century and with the mechanisms of their demise.

Instead of arguing over abstract definitions of socialism, it seems more productive to look for some general descriptive characteristics of socialism as historically observed. Naughton (2017: 3-4) posits four such characteristics: first, the government controls a sufficient share of resources that it has the capacity to shape economic outcomes; second, the government has the goal of achieving outcomes - an allocation of resources - that are different from what laissez-faire would produce; third, the government's policies are targeted to redistribution of income to the working class; and fourth, there is some mechanism that provides some responsiveness of government policies to the preferences of the population. As Naughton himself notes, 'capacity' includes, even as it goes beyond, 'public ownership of the means of production', which has been the cornerstone of the classic definition of socialism since the 19th century. (See Hodgson, 2019: ch. 1, for a fresh reminder of the ubiquity and persistence of this foundational characteristic of what he calls 'big socialism'.)

Despite the fact that Naughton's list is predicated on a socialist government, which did not exist in Haiti, we will argue that revolutionary Haiti fits this bill of characteristics: the state owned and managed most of the valuable land, which was basically the only non-labor production factor in an economy in which agriculture was the only sector; it aimed at maximizing export earnings to enable the government to defend the revolution itself; and this was done for the benefit of the ex-slaves, the working class, who might otherwise have been enslaved again. In our world, where slavery - at least in broad daylight - is a thing of the past, we tend to forget that the taking away, or the giving back, of property rights in one's self is the most fundamental wealth redistribution of all. As to the fourth characteristic, all socialist regimes of the 20th century were one-party states, not democracies; hence, whatever 'responsiveness' there was worked through the institution of the communist party, which claimed to represent the interests of the working class - or, in its latest Chinese incarnation, the educated technical and managerial elites (Naughton, 2017: 19-20). In contrast, the Haitian revolutionary regimes - a type of military dictatorship - lacked the party, which was functionally replaced by the army as a machinery of administrative control, and the army itself relied on conscription and so was anything but a channel of accountability to the masses. Rather, using Hirschman's (1970) dichotomy, the 'voice' mechanism of the party was effectively replaced by an 'exit' mechanism as a constraint on the rulers' power: the possibility to escape or circumvent state control through marronage and through squatting, or de facto, sub rosa privatization of the land. As will be discussed in a later section, this is another new twist that the Haitian experience adds to the outcomes available to a socialist regime.

This paper will first describe the Haitian socialist institutions and their demise, and then turn to a comparison with the system that prevailed in the 20th-century communist states, paying special attention to the kindred case of São Tomé. This comparison, it is hoped, sheds some retrospective light on the relative durability of modern communism and the manner of its collapse. 


\section{The economic systems of revolutionary Haiti}

\subsection{Political and economic background}

On the eve of the revolution, Saint-Domingue had become in less than a century the jewel of the French colonial crown, yielding handsome profits from a plantation economy based on African slave labor and geared toward export to the European markets. The main export crops were sugar, coffee, cotton, and indigo, in this order. In 1789 sugar accounted for $48 \%$ and coffee for $33.6 \%$ of total export value (Lacerte, 1975: 77). In 1789 the total population was reported at 520,000 , of which 40,000 were whites, 28,000 'people of color' or freedmen (free persons with African blood in their veins), and 452,000 slaves (Leyburn, 1966: 18, note 5). The freedmen had been granted their liberty largely because they were the children of white masters by black mothers, or else as a reward for extraordinary service; being full French citizens, often owners of slaves, increasingly prosperous, and increasingly educated, their rise fed the jealousy of the whites who discriminated against them. The ownership structure by class followed closely on the technology and geography of the different crops. The northern plains had the ideal soil for cane production, while the mountainous regions of the south and west were ideal for coffee. Economies of scale dictated differences in optimal size: the typical sugar plantation required 100 carreaux (129 hectares -1 carreau $=1.29$ hectares) of land and 200 slaves, while all other crops could be efficiently grown on much smaller estates (Williams, 1984: 122, 238). Hence the freedmen concentrated on the ownership of coffee plantations, which was more accessible, and consequently were mainly clustered in the south and west, while the north remained the preserve of white planters and black slaves. By some estimates, on the eve of the revolution the freedmen owned between onefifth and one-third of the land and between one-fifth and one-fourth of the slaves of the country (Fick, 1990: 19; Leyburn, 1966: 18).

In August 1791 the slaves revolted and the insurrection spread rapidly, with wholesale massacres on both sides. Given the demographics, the whites had no chance, so all who could began to flee in earnest, while the freedmen tried to use the insurrection to seize control of the colony. Then in 1793 Spain and England took advantage of the turmoil to invade the island. Even though the French commissioners abolished slavery to win the blacks' support against the invading armies, the French troops would soon have been defeated but for the help from the black freedman Toussaint Louverture, who raised an army from among the ex-slaves. By 1798 the Spaniards and the British had been driven out of the colony and in 1799 a mulatto insurgency was put down. Toussaint was now the uncontested ruler of the country and restored law and order.

When Napoleon rose to power in France, he was determined to re-establish slavery in Saint-Domingue and the rest of the French Antilles. A formidable French army landed on the island in February 1802 and, after a fierce fighting, Toussaint was treacherously captured and dispatched to France, where he died in prison a year later. When the French then set about reintroducing slavery, the black generals, led by Jean-Jacques Dessalines and Henry Christophe, took the lead of a spontaneous popular uprising, aided by an epidemic of yellow fever that decimated the French. At this point Napoleon abandoned the project of recapturing the colony. At the end of 1803 the remaining French troops surrendered to the British and on January 1, 1804, Dessalines proclaimed the independence of the Republic of Haiti.

Dessalines crowned himself Emperor and ruled Haiti until his assassination in October 1806. Upon his death the country was divided into a kingdom in the north headed by Christophe (1807-1820) and a republic in the south and west headed by the mulatto Alexandre Pétion (1807-1818); the two powers waged intermittent warfare throughout. Pétion was succeeded by Jean-Pierre Boyer (1818-1843), and when Christophe died in 1820, the north was peacefully reunited to the south, giving rise to a unified Haitian republic ever since.

Despite independence, a defining condition of the regimes that followed Toussaint's was the fear that the French may well try and get their colony back, especially since slavery in the French empire was not definitively abolished until 1848. Only in 1825 did France recognize Haiti's independence in 
exchange for Boyer's pledge to pay a crushing indemnity, which continued to hamper economic development for many decades to come (Lacerte, 1981; Lundahl, 1979: ch. 8).

The revolutionary and civil wars devastated the plantations and caused a steep population decline. A contemporary estimate reckoned that by 1798 two-thirds of the whites, one-fourth of the mulattoes, and one-third of the blacks had either perished or fled (Lundahl, 1985a). Of the surviving ex-slaves, a fraction joined the revolutionary army, another fraction disappeared into the inaccessible mountains to form or join maroon communities, and the remainder stayed on the plantations but stopped tending the export crops and turned to food production. As a result, around 1795 export agriculture was virtually dead and the economy was based on subsistence production.

To run a war economy that had to withstand the onslaught first of foreign armies and then of the returning French, Toussaint needed to import weapons and other war material, which were not manufactured in Haiti, and this required the export crops to be revitalized. To this end, Toussaint chose to go back to plantation agriculture and run it as a centralized system based on a military organization of production, which allowed export agriculture to be revived and the insurgents to succeed (Lundahl, 1985a).

Dessalines maintained the same system for the same reason, i.e. the impending threat of a return of the French. The economy needed to be restarted after the last cycle of war of 1802-03, as most plantations had been burned down and the workers there had turned to subsistence production. The labor shortage was severe: a census taken in 1805 (of uncertain accuracy) showed a population of 380,000, implying a net decline of 140,000 people, or $27 \%$, from 1789 , with women outnumbering men by three to two (Leyburn, 1966: 33-34). The disruption had affected production unevenly: coffee, being a mountain crop that required little tending and did not involve economies of scale, had survived relatively well, whereas sugar, which required heavy concentrations of labor as well as a mill to crush the cane immediately after harvest, had collapsed, and indigo had disappeared from the country and would never recover again.

After Dessalines' death, the division of the country was paired by a bifurcation of the economic system. In the northern kingdom Christophe continued and strengthened the state-controlled plantation system, while in the southern republic Pétion proceeded to divide up the land into small proprietorships, thus jettisoning the plantation system and in effect setting in motion the first in the line of Latin American land reforms that ended up in the creation of a smallholder economy. Finally, in a reunited Haiti, president Boyer made one last attempt at reviving the plantation system; its utter failure marked the final demise of the state system and the government's surrender to the smallholder regime.

The economic institutions and policies enacted from Toussaint to Boyer are the subject of the analysis that follows.

\subsection{Land allocation and management}

Under Toussaint, while the mulattos and those white planters who supported his government were allowed to keep their properties, most of the plantations, abandoned by their French owners, were taken over by the state and rented out to senior army officers, who profited handsomely from it (including Dessalines, Christophe, Toussaint's nephew Moïse, and Toussaint himself). The estates' size was purposely kept large, preventing their dissolution into small holdings favored by vacant ownership: land transfers were only allowed if involving at least 50 carreaux (about 65 ha). All properties had to pay a tax of one-fourth of the crop (Leyburn, 1966: 55, note 23).

Dessalines began his reign by slaughtering the few thousand remaining French for fear that they might act as a bridgehead for a re-colonization attempt. This wiped the slate clean of all French property in the country and made it state property. Furthermore, Dessalines cancelled all the gifts or sales of land made by departing French owners to Haitian nationals and nationalized the properties involved. Finally, he ordered a general verification of property titles which resulted in the government's confiscation of hundreds of estates in the west. Crowning the new order, the Constitution of 1805 dictated that no white man of whatever nationality shall henceforth own property in the country - a stipulation that would remain in force for the remainder of the 19th century. 
These measures resulted in a massive transfer of land into the public domain: in 1806 between two-thirds and nine-tenths of all productive plantations were estimated to be in state ownership (Leyburn, 1966: 39, note 6). The state properties were kept as large as in colonial times and farmed out to high-ranking army officers and government officials, the vast majority of them black. All properties paid an output tax proportional to their workforce, and from the state properties the government took one-fourth of the crop as rent (Lundahl, 1984: 94). Thanks to this, besides pleasing his senior officers and paying for the defense expenditures, Dessalines enriched himself and led a life of extravagant luxury, which did not endear him to the struggling plantation workers and soldiers.

King Christophe created a nobility system that mimicked all the trappings of European aristocracy to reward his most loyal supporters. By so doing he leveraged the vanity of his men for incentive purposes: as the pomp and court etiquette required of them was costly, they were spurred to increase the productivity of the plantations entrusted to them (Leyburn, 1966: 44-45). The new aristocrats were predominantly black, top-ranking military and civil officers, while the mulattos were mistrusted as the black workers increasingly defected to the mulatto-led southern republic which did not know the toil of plantation work (see below). The nobility received the estates on lease at the king's pleasure and the landholdings were kept very large, the concessions being of 400-500 carreaux (516-645 ha; Lacerte 1978: 456). Each estate was taxed at one-fourth of the crop, and in addition another fourth of the crops from the estates leased to the nobles was collected as rent. In his last few years, however, the competitive pressure from the distribution of land to smallholders in the republic forced Christophe to give small land grants to his soldiers (Lacerte, 1978: 458).

\subsection{Production organization and labor incomes}

Under Toussaint, the ex-slaves were ordered back to the plantations and forbidden to leave unless they were enlisted in the army; a rural police ran vagrants down and returned them to the plantations. On these, work was organized in a military fashion by the officers who rented them, who answered directly to Toussaint; in each district, the military commanders were responsible for agricultural production under the direction of Dessalines and Moïse. The workers in each plantation were collectively entitled to one-fourth of the produce, in addition to their subsistence which had to be provided by the proprietor or tenant (Mackenzie, 1830: 139). Except for the last-mentioned feature, and despite the (partial) change of masters, such a system of forced labor on large plantations was reminiscent enough of the slave regime to trigger off in 1801 a workers' uprising in the north, led by Moïse, that apparently advocated the breakup of the large estates and the distribution of land to soldiers and workers, and which was swiftly put down.

Thus Toussaint relied on military-style conscription and replaced the civil administration, which had largely disappeared, with the military - truly a war economy. In turn, Dessalines took over the militarized system set up by Toussaint and ran it with an iron fist, while starting a massive program of fortifications in the interior. Little distinguished the system from former slavery when it came to the daily routine of laborers, even though they were still paid one-fourth of the crop.

The same system remained in place in the northern kingdom under King Christophe, but he leaned more toward incentives rather than naked coercion to make it work (Leyburn, 1966: 42-51, 317; Mackenzie, 1830: 146-152). Workers were still attached to the estate where they were born and were still entitled to a quarter of its produce; but this share was now to be shared out in predetermined proportions, from the drivers and the craftsmen through the stronger, more productive laborers down to the weaker ones. In addition, like in the old slave regime, each family had its own garden plot to raise the food for their sustenance. Each estate was provided with a nurse, a midwife, and a visiting doctor; the work day was minutely regulated, and Sundays were free for the workers' leisure and the trading of their surplus produce in the town markets. On the other hand, since Christophe undertook the construction of fortresses and royal palaces on a large scale, each estate was to supply a quantity of food for the upkeep of the construction workers and a proportion of 
its workforce every Saturday for corvée labor on such works - a sort of taxation in kind to finance construction investment.

\subsection{Economic performance of the state system}

Toussaint's experiment lasted no more than one and a half years in the south and four to six years in the north and west. Nevertheless, the system worked well. In 1801 exports had recovered to $13 \%$ of their 1789 level for sugar, to $57 \%$ for coffee, and to $35 \%$ for cotton (Lundahl, 1985a). Under Dessalines too, considering the forbidding constraints, production did well: although no hard figures are available, sugar continued to contract, aided by a long-term decline in its world-market price, whereas coffee exports stabilized at some 30 million pounds, about $45 \%$ of the pre-revolutionary levels.

Christophe encouraged foreign trade especially with the British, and overall his system worked, raising a government revenue that was larger than at any time since the 1791 revolution, and bequeathing a substantial treasury to the republic at Christophe's death in 1820 (Leyburn, 1966: 51). We have figures for exports from Cap Haitien, which was the only trading port for Christophe's kingdom and hence should give us the total exports for this period (Mackenzie, 1830: 157, 167-169, and note JJ in the Appendix, no page). Sugar exports slowly increased from half million pounds in 1807 to some 3 million by the end of the period; although a pale shadow of the sugar exports of colonial times, these data indicate some modest success in reviving plantation agriculture. Coffee exports fluctuated between 4 and 10 million pounds, with no trend in either direction - not a bad achievement given that the best coffee land was in the south. Finally, a beginning was made in the production of commodities that had not been grown in colonial times, including cacao, dye woods, and tobacco.

\subsection{The economic rationale for the state system}

As we have seen, the defense requirements were paramount in the successive leaders' policies. Toussaint's chief objective was to enable the country to import weapons to sustain the war effort, and Dessalines kept a regular army whose size has been estimated between 15,000 and 37,000 men (i.e. between one-tenth of the male population and one-tenth of the entire population; Leyburn, 1966: 36, note 4), and which still had to be supplied with imported weapons and ammunition. In addition, both Dessalines and Christophe engaged in a massive construction program of fortresses and royal palaces, which required a heavy commitment of labor. Just as important as defense, however, was another objective, namely to maintain the unity of the coalition of generals that supported the leader by satisfying them with adequate wealth, lest they defect to the enemy or to the mulatto opposition. The two objectives together translated into maximization of government revenue, and this implied the revival of export-oriented agriculture (Lundahl, 1985a, 2013b).

What explain the Haitian leaders' choice of state farms to run the plantations? After all, the nationalized land could have been divided up and given to workers on long-term lease or right-of-use contracts, subject to a system of taxes and government procurement, as happened in the de-collectivization drives in China and Vietnam in the 1980s. Lundahl (1984, 1985a, 1985b, 2013b) offers a convincing explanation based on transaction costs. Given the economies of scale that characterized sugar production with the technology of the day, when the optimum size of the mill was large, a smallholder system would have involved high coordination costs to have the farmers bring the cane harvest to the mill in time. Even where economies of scale were unimportant, as in coffee production, first of all the produce from a large number of scattered production units would have had to be collected for export, and given the poor transportation network, collection costs would have been high. Second, the smallholder alternative entailed heavy costs for creating the right output mix, as this required shifting producers away from their natural inclination to food crops and toward export crops, which in turn involved either resort to coercion or provision of the right incentives. Third, peasant incomes would have had to be taxed and the tax revenues redistributed to the ruling group of top army officers. Finally, all these costs together would give rise to an additional, costly requirement: an 
administrative apparatus to take care of coordination, collection, direction, and redistribution; such an apparatus would have had to be created from scratch as the entire colonial bureaucracy was gone. By contrast, maintaining the large plantations and running them as state farms in the hands of the military elite would make all of these costs disappear or shrink. On the other hand, the plantation system involved the costs of supervising the workers to deter shirking and cheating if, as seemed inevitable, adequate incentives to effort were lacking. The means to this, however, were the well-tested tools that had driven workers under slavery, albeit somewhat mitigated, and the overall control of plantation discipline could be entrusted to the army, whereas production coordination, planning, and taxation obviously could not. Therefore, the transaction costs of a peasant-holdings-cum-taxation system appeared to be so much greater than those of the state system as to be prohibitive.

\subsection{The demise of the state system}

In the southern republic, starting in 1807, the Senate restored the properties confiscated by Dessalines to their former owners or de facto possessors, mostly the mulatto elite (Lacerte, 1975; Leyburn, 1966: 51-64). To stimulate production, the traditional tax of one-quarter of the crop was abolished and replaced by an excise tax on coffee exports, whereas sugar production was set tax-free. Moreover, the government stabilized agricultural incomes by purchasing large quantities of coffee and sugar in years when their prices were low. Predictably, as a result of the tax cuts and the price subsidies, government revenues sank.

Pétion, however, advocated a wider distribution of land to the soldiers and workers, both as a reward to the blacks who had fought for independence and as a social base of the republic; this was resented by the mulatto elite whose privileged status was based on property ownership. He viewed the land distribution as the only way to strengthen, somewhat paradoxically, the position of his class by reconciling the black majority to mulatto rule, thus avoiding an internal war along color lines from which only Christophe would benefit. (We will examine the deeper economic forces underlying Pétion's decision in the next section.) The clash came to a head in 1809 when Pétion, supported by a largely black army, established his personal dictatorship, thus gaining a free hand to carry out his radical land reform. With a series of decrees, he began to give the land away in full ownership, first to the war veterans in accordance with their rank, then to all officers on active duty, and finally to government officials in lieu of unpaid salaries. Eventually most of the public domain in the south had been effectively alienated in perpetuity.

To estimate the impact of these reforms on wealth distribution, some data are available (Lacerte, 1975: 83-84). According to a 19th-century estimate, 76,000 carreaux $(98,040 \mathrm{ha})$ were distributed among 2,322 civil and military officers in proportion to their rank; below these were the common soldiers who received grants of 5 carreaux. We have no direct information on how many soldiers benefited, but we know that around 6,000 soldiers received grants of 5 carreaux (6.4 ha) between 1809 and 1825 , including the early years of Pétion's successor Boyer who also distributed some land. If we take a mid-range estimate of the size of the Haitian army under Dessalines at 20,000 men and assume that a majority remained in the northern kingdom which was more populous, Pétion's army would be left with less than 10,000 soldiers, so that about half of these would have received land during his presidency - a substantial redistribution. A French writer of the following generation sympathetically concluded that Pétion had 'republicanized' the land (Lepelletier de Saint-Remy, 1846: I, 169). He may well have been right. If we assume a population of at most 150,000 at the beginning of the republic (out of 380,000 reported for the whole country in the 1805 census) and take account of the substantial, if unquantifiable, marronage - squatters on unclaimed lands on the mountains - which was rife especially in the south, the reference population for the reform might have been in the range of 100,000 to 125,000 . Assuming an average family size of five (Leyburn, 1966: 76), that would give us 20,000 to 25,000 households, and if the beneficiaries of land grants belonged to different households, as seems reasonable, somewhere between 29 and 36\% of households (including both officers' and soldiers' households) would have benefited from the land reform. 
The economic consequences of the parceling out of ownership were soon felt (Leyburn, 1966: 57-60). The new owners of small farms turned to food crops, so the continuation of export crops depended on the larger estates. To secure labor to the plantations Pétion resorted to a system of sharecropping contracts, whereby the landlord leased his land in large or small plots to tenant farmers and shared the income in half with them; in turn, if the tenant hired workers he had to share his half of the income with them, and the workers' collective fourth was apportioned to individual workers in proportion to skill and ability (like under Christophe). This was the same distribution of plantation income as prevailed under Christophe for the state properties (one-quarter to the workers, onequarter as tax plus one-quarter as rent to the owner, and one-quarter left to the tenant) except that the income sharing took place from each tenant's plot instead of from the whole plantation - hence a shift from collective to individual incentives to effort. In addition, the landlord must provide the sugar mill where cane was grown, assign a garden plot for the tenant's use, provide medical care and other social security benefits. Punishments were stipulated for breach of contract; however, the dreaded corporal punishments of old were abolished by law. Finally, but crucially, the office of 'inspector of cultures', whose duty under the previous rulers it was to see that crop cultivation proceeded according to schedule in each district and who could mete out penalties for production shortcomings, was abolished.

The last mentioned changes proved decisive. The removal of the monitoring and enforcement mechanism and the softening of punishments for non-compliance made contract enforcement toothless; hence, predictably, unmoved by the generous wage and social security package, the workers began to drift away from the cane fields to their garden plots. On the other hand, given the investment and social security constraints, expected net profits proved insufficient as an incentive for the landowners to keep the plantations running, so they broke them up and leased them out in small parcels, resigning themselves to make do with whatever they could get. As a result, the tenants shifted cultivation from sugar to coffee which required little tending, large-scale agriculture crumbled, and sugar production collapsed, while coffee export was able to hold its own but could not make up for the revenue gap. National income fell and government finances sank further.

When Christophe died, Pétion's successor Boyer inherited the northern kingdom and ruled over a unified Haiti (Lacerte, 1981; Leyburn, 1966: 64-87). While in the former republic most of the land had been privatized and parceled out by Pétion, the north still contained many large plantations in the hands of a black elite; however, the removal of coercion following Christophe's death brought large-scale production there to a near halt. In a last effort to revive the plantations, in 1826 Boyer issued a Rural Code that was essentially a re-enactment of Christophe's system, which again attached workers to the land and required them to sign an individual contract with a proprietor or leaseholder. Crucially, enforcement was again entrusted to the army. Soldiers were to be assigned to each plantation and receive their living from it, in return for preserving order and work discipline, and they were answerable to their military superiors.

Unlike its model, however, Boyer's system ended in utter failure. We postpone to the next section the economic analysis of the ultimate demise of the plantation system. But at bottom, the workers simply ignored the code, managed to acquire possession of a bit of land, however small, and so earned an exemption from contracting. Leyburn (1966: 70-71), on the authority of contemporary testimony, convincingly argues that the workers could get away with it because the army - the notional enforcer of the code - had ceased to exist as a disciplined force, and with it all authority of its officers. In turn, paradoxically enough, this can be put down to Boyer's greatest diplomatic success: the settlement of 1825 that achieved full recognition of independence from France, albeit at a heavy financial cost (see above). Once the threat of a return to colonization and slavery was removed, the motive that had kept the Haitian soldier on his line of duty, and which had made him an effective driver of plantation labor under the previous regimes, vanished and military service became a sinecure. At the same time, and for the very same reason, the officers-turned-managers no longer felt compelled to police their own behavior and discipline their workers, implying a sharp rise in the governance costs of the state plantation system. 
Thus Boyer's Rural Code lapsed into oblivion, the remaining large estates were broken up into small landholdings, and estate values sank, until it was no longer worthwhile for an owner to try to prevent squatting on his estate. By the end of his presidency, probably not a single large plantation was still intact. Sugar disappeared from Haitian exports until well into the 20th century; although coffee cultivation managed to survive, it made Haiti totally dependent on a single export crop. This systemic failure did not just cause a long-term decline in national income and entrench a poverty trap, but also entailed ominous consequences for the social evolution of the country to this day: a class cleavage between rural and urban Haiti - the former populated by a black peasantry, the latter by a light-skinned, educated middle class whose elite status revolved not around land ownership, which had become 'common' and worthless, but around avoidance of manual labor.

The obverse side of the color divide, however, was egalitarianism in property ownership. Leyburn's (1966: 51-52) comments on Pétion's reforms are worth quoting in full:

\begin{abstract}
Almost all Latin-American countries in the nineteenth century exhibited one common feature: an aristocratic landowning class lording it over peons. Haiti did not follow this pattern. She had aristocrats and peasants, but the aristocrats did not own most of the land, and the peasants were not peons. If later rulers had kept the organization of economic life begun by Toussaint and developed by Dessalines and Christophe, it is almost certain that Haitian social evolution would have resembled that of the rest of Latin America, for it would not have been a great change from feudal holdings to absolute ownership of land by the influential.
\end{abstract}

The creation of the Haitian peasantry was then completed during Boyer's rule (Leyburn, 1966: 75-79). By the end of his presidency, in 1842, it was estimated that one-third of the population owned their land and another third squatted on land that technically did not belong to them but from which they were never ejected. The remaining third still worked as wage laborers or sharecroppers but would gradually become de facto owners as the legal landowners, unable to wield either sufficiently juicy carrots or sufficiently hard sticks, gave up driving or supervising them.

\title{
3. Agrarian socialism and its demise: 20th-century comparisons
}

\subsection{Haitian socialism and its modern counterparts}

The economic system of revolutionary Haiti was not the product of prior design or ideology but the child of three parents: the slave revolt and war of independence, the vanishing of existing ownership rights, and dire economic necessity. The first two factors together wiped the slate clean for the revolutionary leadership to allocate property rights and direct the use of resources as they saw fit, unencumbered by pre-existing claims and freed from the need to decide which owners should or should not be expropriated: practically all plantations had become vacant property following the flight or slaughter of their French owners. The pervasive threat of return of the colonial powers for decades after independence made it imperative for the government to maintain a large standing army and procure weaponry on a massive scale, which in turn, as none of it was produced in the country, dictated exclusive priority to the export crops. Haitian socialism was the child of these three factors. If there was any 'ideology' behind it, it was the bare needs of survival as a free people, while the system that could best meet such needs was dictated by economic and political logic, not by ideology. Then, as with any politico-economic system of the real world, for such a system to have any permanence it had to be institutionally stable, which implies that its key players - the military elite - had to be given sufficient material incentives to cooperate and hold the system together rather than defecting and breaking it up - a distribution constraint.

The system's socialist core is not immediately obvious because of some features that are not germane to modern socialism as well as some that are typical of it but are not found in Haiti. Among the first are Christophe's nobility and the so-called serfdom; the pairing of the two led observers to speak of 'feudalism'. Historically, however, European feudalism was a system of contracts between 
king and vassals while none of it existed in revolutionary Haiti. Though nobility and socialism make for strange bedfellows, this was no more than a way to create officials that would be loyal to the leader and to spur them to high effort - names for such things did not even exist in the ancien régime. The binding of workers to the land was indeed not typical of communist regimes in their normal state, but not unknown either when they were under pressure - witness the restriction on mobility from country to town in China and the freezing of workers on their place of employment in Russia under War Communism and then again during World War II. Newly freed slaves are indeed a unique constituency in the history of socialism, but wholly in keeping with its systematic tendency to target producer groups as constituencies, including such oddities (from an orthodox Marxist standpoint) as low-caste groups in India and propertyless lamas in Mongolia (Ferrero, 1994).

On the missing side, a key feature of the classical Soviet-type economy that was conspicuously absent in Haiti is economic planning. However, beside the fact that central planning was also absent from other socialist economies in certain periods (and from São Tomé throughout its socialist experience - see below), it was not needed in Haiti. The goal of the state sector was as simple as can be: maximizing the revenue from export of a handful of plantation crops, and since prices were set by world markets, this was tantamount to maximizing marketable output; no other sector had existed since colonial times except for subsistence farming that could be left to its own devices, and after independence there was no hint of any beginning of industry or services such as mass education. The plantations themselves were vertically integrated concerns that produced their own elementary inputs, including the foodstuff for the labor force, so the exchange of intermediate goods was not an issue. Some strategic decisions were evidently made, including the subsidiary development of a few crops that were not grown in colonial times and the building of forts and palaces; the latter works, though, were carried out under Christophe (and presumably, under Dessalines too) by ordering plantation workers to provide corvée labor - the earliest, coarsest form of labor direction. Planning, however, is essentially coordination among firms and sectors, and this was neither required nor possible. In a sense the leaders were lucky: the literate mulatto group was so small that the drafting and implementation of a multi-sector plan through a state bureaucracy would not have been feasible.

This may be a good place to ask whether the Haitian system might not be labeled state capitalism rather than socialism - an issue arising from an old Marxist doctrinal concern and discussed recently with regard to China (Naughton, 2017: 20 ff.). State capitalism is usually taken to be a system of state-owned enterprises that use markets to maximize profits to the benefit of the ruling class. In this case, however, the reliance on markets did not stem from a political choice between plan and market: if maximization of government revenue was the overarching objective, there was only one sector capable of producing a surplus and, by the standard small country assumption of international trade theory, this sector could not help but sell to the world markets at world prices. Therefore, in Haiti socialism and state capitalism tended to be trivially identical. The army officers who rented and ran the plantations were filling the role of the missing bureaucracy and managerial class that performed this function in the communist systems. This export market orientation, as the only option available to an agrarian regime born of war and revolution, is also the most obvious difference with traditional systems of compulsory labor on public lands such as those practiced by many ancient Native American societies. It hardly needs elaboration that the more instructive comparison is the one with modern socialism, rather than with traditional state agriculture.

The greatest prima facie objection to classifying the Haitian system as 'prehistoric' socialism may be its glaring inequality in income distribution. We detailed in the previous section the huge gap in material welfare that separated the leaders and their clique from the mass of workers, tied to the plantations and subjected, their wages and social security benefits notwithstanding, to a labor discipline that was in effect an attenuated version of the slave regime. Lundahl (1985a, 1985b, 2013b) emphasizes this point and sees the revolutionary regime as the starting point of a process that culminated in the creation of a predatory state, run by kleptocrats, that was to characterize Haitian society for most of the 19th and 20th centuries. However, leaving subsequent history aside, a high income of the ruling class per se could disqualify a system from belonging in the socialist club only in the land of egalitarian 
utopia. In the 'real' socialist systems of the 20th century the ruling class, typically crystallized around the communist party - the nomenklatura, as it was dubbed - enjoyed incomes that were a multiple of average wages, and could be high multiples at the top level.

Several estimates are available. In a recent study based on internationally comparable criteria (Novokmet et al., 2018: 212-214, 217-219), the top 1\% income share in Russia was around 4-5\% in the Soviet period, which means that the top $1 \%$ income recipients earned 4-5 times the average income; in other East European communist countries the top 1\% share was lower, around 3\%. In his classic survey of Soviet inequality Bergson (1984: 1085 ff.), relying largely on Matthews (1978), reports data on a Soviet 'elite' defined as people earning incomes above a threshold of 3.1-3.8 times the average wage of Soviet employees in the early 1970s (which, however, understates the inequality because it does not include collective farmers, whose incomes were lower than the average wage); this group amounted to $0.2 \%$ of all gainfully employed. However, both sets of estimates avowedly rely only on monetary incomes, which under Soviet conditions were a poor measure of material welfare for several reasons: first, prices of 'necessities' such as housing, utilities, and public transportation were subsidized, and second, owing to the system of fixed consumer prices that were typically below market-clearing levels in most markets, shortages were ubiquitous, which dampened the real value of money income differentials; both factors had an equalizing effect on the real income distribution. Partly to shield the high-income groups from the shortages, a system of non-price discrimination became entrenched, involving a vast array of consumption privileges in kind for the nomenklatura. These were channeled through 'closed shops' supplying licensed customers with deficit goods, housing, cars, vacation resorts, and more, which could amount to a very substantial, if unquantifiable, addition to the money incomes. Of course such a distribution in kind augmented the real relatively to the money income differentials. The system had close parallels in the other countries of the Soviet bloc.

This system was distinctive of Soviet-type socialism vis-à-vis the Haitian case, where the elite's incomes were thoroughly monetized. The natural question then arises, why not simply pay higher money incomes to the persons in question? Bergson (1984: 1089) offers two reasonable conjectures (apart from the need to deal with the shortages, which has no Haitian counterpart): first, the monetization of privileges would make them more conspicuous, hence politically disturbing, and second, the distribution in kind reminded recipients of their dependence on the continuing favor of the leadership, and hence kept them politically loyal, in a way that higher market incomes would not. In contrast, in Haiti the leased estates could be simply taken away and reassigned for political reasons. This points to an important systemic difference: the impromptu nature of Haitian socialism implied that there was no egalitarian ideology to dictate that privileges must be hidden from view, and no socialist party to control and enforce a politically desirable income distribution. In Haiti, elite privileges could be both greater (though to a degree that we cannot readily quantify) and more naked than under Soviet-type socialism.

Agriculture is the sector that saw the greatest variety of ownership arrangements under 20th-century socialism (Pryor, 1992). The range included countries where collectivization of agriculture was either never seriously attempted, soon undone, or failed amid widespread crop destruction and cattle slaughter (Yugoslavia, Poland, Nicaragua, Laos, Mongolia in the 1930s, and most of the African countries; see Pryor, 1992: Table 1.1, p. 19); in other countries, including China and Vietnam in the 1980s, agriculture was de-collectivized, though not privatized, while the regime still remained communist. This was, however, possible because the state could rely on its control of other key sectors outside agriculture. Vacancy of landed estates previously owned by foreigners, like in Haiti, occurred in parts of Eastern Europe after World War II and in many African countries after decolonization. Where extensive collectivization was successfully carried out and maintained throughout the life of the communist regime, it took two forms: state farms, which are basically like a factory in the field that is owned and managed by the state and worked by wage labor, and collective farms, which are theoretically a form of producer cooperatives where the net incomes (as well as the risks of production shortfalls) are shared by the members. State farms were the dominant form in 
São Tomé, Cuba, and Bulgaria; collective farms were the dominant form in North Korea, China, Vietnam, Mongolia from the late 1950s, and all the other European countries that did collectivize; the Soviet Union and Romania featured a mixture of both forms (Pryor, 1992: Table 4.1, pp. 99101). In practice, however, in most cases the collective farms were subjected to planned choice of crops and compulsory deliveries at fixed prices, which tended to blur the difference with state farms; moreover, over time the Soviet Union saw a gradual conversion of collective farms into state farms. The Haitian system falls squarely in the state farm class, so it is fully in line with the mainstream of modern socialism. The one feature that seems distinctive to it - the leasing out of the farms to private individuals who would manage them on behalf of the state - can be seen as an expedient that substituted for the missing bureaucracy and provided incentives to maximize production: the leaseholders were high-ranking army officers and were constrained by mandatory wage bills, taxes, and rents, leaving their profits as a residual. As discussed above, these residual claimants enjoyed handsome incomes, which accounts for the more glaring inequality in Haiti vis-à-vis 20th-century socialism.

\subsection{Transition from socialism}

What explains the ultimate demise of the socialist plantation system? Lundahl (1979: 268-277; 1985b, 2013a: ch. 1) offers a comprehensive explanation. The land distribution and discontinuation of forced labor initiated by Pétion were triggered by political factors. However, a deeper economic force would have probably achieved the same final outcome irrespective of political conditions: the relative scarcity of production factors. Sugar production was capital- as well as labor-intensive and exhibited substantial economies of scale. Sugar factories and irrigation works, however, had been largely destroyed by the wars and would have cost staggering sums to be restored, but none of the three possible sources of capital was available: foreign investment was not forthcoming due to the international isolation of the only independent black state in the world; the domestic capital market was practically non-existent; and the scarce and declining government revenues were totally absorbed by the high military expenditures and, after 1825, by the payment of the huge indemnity to France (Lundahl, 1979: ch. 8). On the other hand, other traditional export crops, such as indigo and cotton, did not require much capital but, if the efficiency of colonial days was to be maintained, did require relatively large concentrations of labor and tight labor discipline.

Labor, however, had itself become a scarce factor. As we have seen, total population had declined severely to the 1805 census; and a major way for workers to get away from plantation labor was marronage, due to the fact that unoccupied land continued to exist on the frontier of settlement. As in many other slave systems of the Caribbean and the Guianas, this escape route had existed in the mountains throughout the period of slavery and was further enhanced by the wars and independence. Finally, and most importantly, the material and psychological legacy of slavery, combined with the many years of bonded labor under the revolutionary regimes, had put a high premium on freedom, so that the reservation wage that would have been necessary to induce the workers voluntarily to join the labor gangs on the plantations became prohibitively high. In theory, such high wages could have been affordable with sufficiently high prices of export products, but intensified competition from other Caribbean islands produced a downward trend in sugar and coffee prices throughout the first half of the 19th century.

Summing up, the emerging factor proportions could not support the socialist system in the long run: both capital and labor were scarce while land was plentiful; indeed, during most of the 19th century, marginal land was in unlimited supply, hence no free man could have been forced to pay rent on it. Therefore, even if the necessary capital to restore the sugar mills could be found, the labor supply constraint alone would have been sufficient to make the system unviable. Most workers had alternative opportunities to gang labor and preferences opposite to it, so they could be kept on the plantations only by coercion; when the enforcer of coercion - the army - collapsed under Boyer the plantation system was doomed. It basically crumbled under its own weight. As Leyburn (1966: 87) drily sums 
up, 'where food is easily got, the government gentle, and the people ignorant, one hardly looks for progress'. A modern economist can read into the story a reassertion of the fundamental consumption/leisure choice, which had been so thoroughly suppressed under slavery that even the most generous revenue sharing and social security plans devised by the socialist system could not trump the attraction of the freedom of working on one's own. At a more fundamental level, the Haitian story can be read as a perfect instance of Domar's (1970) celebrated free-land hypothesis in its starkest form: in an agricultural economy where capital is unimportant, free labor, free land, and the extraction of a surplus by non-working landowners (whether socialist or otherwise) cannot exist together; the latter requires that either the land or the labor be unfree. While the hypothesis has long been applied to traditional agrarian societies, the small contribution of this paper is to show that it may prove the undoing of a socialist system as well.

The demise of socialist agriculture in Haiti can be assessed in the context of the de-collectivization of agriculture in the transition economies of the late 20th century (Rozelle and Swinnen, 2004). A first group of countries was led by communist China and Vietnam, which in the 1980s broke up the large collective farms into small family farms and distributed income and control rights on the land, though not full ownership rights, to the households who were already farming it, subject to some delivery contracts or quotas with the state. In the 1990s Albania, Armenia, Azerbaijan, and Georgia followed the same course and went further to full privatization of the land. In a second group of countries, comprising Central Europe, the Balkans, and the Baltic countries, the dominant procedure was restitution to the owners who had been expropriated by collectivization, or to their heirs. Such restitution did not necessarily lead to fragmentation because most new owners were not interested in returning to agriculture, so they often rented their land to those who were already farming it in the collective or state farms. As a result, privatization produced a sector of large corporate farms alongside a sector of small family farms. A third group of countries, comprising the former Soviet Union (except for the countries reviewed above), took a tortuous road that was supposed to eventually privatize the land by distributing 'shares' to individuals, but ended up for the most part in the effective granting of property rights in the land to the former collective or state farms that already worked it, not to individual owners, turning them into private corporate farms to the benefit of the insiders - the managers. This hindered the development of family farms.

Against this background, the Haitian de-collectivization is distinctive. Restitution was of course never an issue, as the Haitians wanted nothing to do with their former colonial masters. Privatization to corporate commercial farms, whether owned by insiders or outsiders, was also not an issue as the labor to work them could not be obtained in the absence of coercion - that was precisely the problem that undermined the viability of the state farms in the first place. Instead, the outcome of Haitian de-collectivization can be divided into two parts. One is the extra-legal, anarchic type of privatization: the de facto grabbing or squatting on the land by those who previously worked it. This superficially resembles the outcome observed in the first group of countries above - individual farming by households previously employed in the collective farms - but in the total absence of any contract or control by the state that could ensure the delivery of export crops. The other part is the legal privatization, carried out mostly by Pétion, which had a well-defined group of beneficiaries, the war veterans and the army officers on active duty. This is distinctive enough but has parallels in other countries: in the Soviet-type systems, privatizations in agriculture and other sectors often rewarded the party apparatchiki who were insiders to the socialist firms being privatized; in Haiti the army was the functional equivalent of the communist party. In a fundamental sense, in both cases the socialist system collapsed when the agency that enforced it - the communist party and the army, respectively - collapsed. On the other hand, the Haitian privatization, while a ticket to general poverty, was remarkably egalitarian, something that can hardly be said of most other socialist countries. 


\subsection{A closer comparison: São Tomé}

One formerly socialist country presents features close enough to Haiti's to provide an instructive comparison: the former Portuguese colony of São Tomé e Príncipe, a tiny island country in the Gulf of Guinea (Keese, 2011; Pryor, 1992; Seibert, 2016). Unlike the other Portuguese African colonies which fought long anti-colonial wars, São Tomé was granted independence in 1975 without firing a shot, upon which its émigré liberation movement set up a one-party socialist state; this gave way to liberalization and the first free multi-party election in 1991, in keeping with the general collapse of communism worldwide. At independence, the population of about 80,000 was made up of two groups: creoles, or descendants of Portuguese settlers and former African slaves who had been living on the islands for centuries, and African contract laborers more recently imported from other Portuguese colonies but who often chose or were forced to stay on the islands. Virtually all the cultivated area was taken up by a small number of large plantations specializing in a single export crop, cocoa beans, and owned by mostly absentee Portuguese owners; these were worked by the contract laborers, as the creoles would not hear of plantation work, which smacked of slavery to them, and lived in the towns. After independence, most of the Portuguese fled and did not try to reclaim their estates, which were rapidly nationalized, consolidated, and turned into state farms - 15 in number - giving the government control of $95 \%$ of the farmland. Since most of the population was landless, nationalization of the foreign plantations was broadly popular. Being a monoculture economy geared to export markets, economic planning was not necessary, which was fortunate enough as a competent bureaucracy to replace the departed Portuguese was completely lacking. The social cleavage between creoles and plantation workers, who were still the non-native contract workers and their offspring, was complete; the ruling socialist party represented only the former while the latter were completely estranged from politics. The government set up a labor inspectorate and a network of party committees on every plantation that were in charge of enforcing work discipline and punishing malfeasance, such as workers' shirking or growing food for their own consumption; no positive incentives were apparently used. Clearly, socialism was not for these laborers.

In the ruling party's plans, like in many post-colonial developmental states, maintaining the plantations was to be the key to export earnings that would permit diversification and reduction of import dependence. This, however, never happened. Due to mismanagement, corruption, poor work incentives, and lack of investment, performance of the state farms steadily deteriorated and cocoa output fell throughout the 1980s, collapsing the government finances, until the government put itself under the protective wing of the IMF and the World Bank. These institutions recommended dismantling and privatization of the plantations. Soon after the democratic transition of 1991 the government embarked on land reform. The plantations were broken up into small farms granted to the plantation workers and medium-sized farms granted to local merchants and politicians. A total of some 9,000 small farmers received land (Seibert, 2016: 1003) - the first time ever that former plantation workers could enjoy land rights. These workers might have totaled 20,000 individuals, including family members, at independence (Keese, 2011: 378), so the land distribution came close to covering the whole plantation workforce - a remarkably egalitarian outcome. The land reform aimed to increase cocoa output toward historical levels and diversify agricultural production but failed: cocoa output continued to stagnate but at the same time to account for almost the whole of export revenues. In turn, the failure of land reform accelerated rural outmigration, increasing urban poverty and emigration abroad. The country remains to this day heavily dependent on foreign aid for its government budget, with the political elite jostling for slices of the foreign cake.

Despite the distance in time and international situation, the stories of Haiti and São Tomé present striking similarities. In both countries, a prosperous colonial economy turned on one or a handful of export crops, while other products were virtually absent; being tropical economies, the crops' production was organized into large plantations worked by dependent laborers (slaves or foreign contract workers) and owned by foreign colonials. At independence, the foreign owners fled or died, leaving their property vacant and hence available to be nationalized without harming domestic interests. 
The new state was organized as a dictatorship, whether military or civilian. The new ruling class could ensure its continuing hold on power and income (which required buying foreign weapons and financing large government budgets) only by continuing reliance on the export crops, and this could be efficiently done only by holding the plantations together. These were therefore run as state farms, which under the circumstances required only driving the workers hard but no central planning as there were neither intermediate goods nor other economic sectors to coordinate and supply. This made the socialist experiment temporarily viable despite the fact that a skilled bureaucracy that could shoulder any planning tasks was simply non-existent. In turn, driving the workers to ensure their productivity required either binding them to the plantations under military supervision where free land was available for them to run away to (in Haiti), or leaving them on the plantations and dispatching government inspectors where the workers were foreigners and had nowhere to escape to (in São Tomé). The plantation system therefore collapsed - and the state farms and socialism itself with it when either the enforcer of labor discipline fizzled out (in Haiti) or the productivity was so dismal as to force privatization. Finally, the de-collectivization was remarkably egalitarian: in one case, yielding to the pressure of war veterans and officers to be rewarded for their service; in the other, yielding to the pressure of plantation workers who claimed their share of land rights. In both cases, such an outcome was made possible by a class cleavage that dated back to colonial times but survived and grew deeper with independence: an urban elite that would not touch field work (mulattos or black creoles) versus a mass of rural workers who were disenfranchised from political influence (ex-slaves or foreign contract laborers).

On the other hand, two important differences stand out. First, the political leadership in São Tomé embraced a Marxist ideology with a socialist program and close links with other socialist states, whereas Haiti was the first and only such experiment in the world of its time with not the slightest hint of such an ideology - not even a wording for it. Second, São Tomé's state was controlled by a socialist mass party, whose membership in the mid-1980s comprised of $6.2 \%$ of the adult population (a percentage in line with that of the Asian communist regimes, though lower than in most European ones; Pryor 1992: 363-365); by contrast, Haiti had only the army as an organized force - indeed, mass parties of any kind were unknown in the world of the early 19th century. However, São Tomé's socialist party represented exclusively the creoles, not the plantation workers. Therefore, in neither country did the sole organized force represent the field workers qua workers: in one case it represented a nonworking group, in the other the soldiers or ex-soldiers. The strikingly egalitarian outcome of de-collectivization - a poor peasantry in both cases - may then be seen as due to the fact that, when the socialist experiment collapsed, the urban elite had no use for land ownership as it returned no profit, so the land might as well be given away to appease the resentment of dispossessed groups war veterans or propertyless laborers.

All in all, Haiti's natural experiment in socialism, backed at some remove by its São Tomé twin, holds several lessons in political economy. First, a socialist, state-run system of large-scale agricultural production is conceivable and temporarily sustainable even in the absence of both a socialist ideology or program and a socialist party. Second, however, a party rooted in a field workers' constituency could make a difference by providing an incentive mechanism in the form of a career ladder, from the grassroots through the party apparatus, linked to the state farm's success; this in turn would drive the party cadre to devote effort to both disciplining the workers and sharing the rewards from performance with them. That was crucially lacking in both Haiti and São Tomé. Granted that the inherent inefficiencies of state farms, and state-owned enterprises generally in the historical socialist economies, would eventually have spelled the doom of a classic socialist system anyway, a workers' party might have provided stronger political incentives to economic performance and therefore, possibly, given the system a longer lease of life. On the other hand - and this is a third lesson - at the system's demise, the party cadre would have been there to make sure that the best pickings from privatization fell into their hands, as observed in most post-communist transitions and opposite to what occurred in our two countries. 


\section{Summary and conclusion}

This paper has resurrected from oblivion the economic system established by revolutionary Haiti around the turn of the 19th century and shown that, contrary to the prevailing scholarly opinion, it can be accurately described as agrarian socialism. Its working and its demise have been compared with the parallel experiences of 20th-century socialist regimes and their transition to a market economy. The interest of this remote case lies in the fact that the Haitian socialist experiment was unintended and accidental - the child of three circumstances: the revolutionary overthrow of slavery and colonialism, the vanishing of pre-existing property rights, and the need for the government to maximize export revenues to defend the revolution. This could efficiently be done only by maintaining plantation agriculture as a system of state farms, and to ensure the cooperation of the only organized force in existence - the military elite - the state farms had to be leased out to the top-ranking officers who could thus profit from them. In the presence of free land, maintaining the plantations in turn required binding the workers to the land with the army enforcing work discipline; when the military coercion waned, the system collapsed and gave way to a system of smallholder agriculture.

Thus the Haitian story can be read as a historical natural experiment in socialism in the absence of two defining characteristics of 20th-century socialism: the ideology and the mass party. The experiment yields three lessons in comparative political economy: agrarian socialism is somehow viable without those features, but it lacks political incentives to economic performance and is therefore shortlived; the income inequality is greater and more blatant; and the privatization that terminates its life tends to be egalitarian. This should give pause to the many scholars who, in the tradition of Hannah Arendt, still consider ideology as the key to understanding historical communist systems.

Acknowledgements. An earlier draft of this paper was presented at the third conference on The Political Economy of Democracy and Dictatorship (PEDD III), University of Münster, February 28-March 2, 2019, where participants provided interesting discussion. The author is indebted to Mats Lundahl for close reading and advice and to Raul Fabella, the editor and the reviewers of this journal for helpful comments.

\section{References}

Bergson, A. (1984), 'Income Inequality Under Soviet Socialism', Journal of Economic Literature, 22(3): 1052-1099.

Cantoni, D. and N. Yuchtman (2020), 'Historical Natural Experiments: Bridging Economics and Economic History', in

A. Bisin and G. Federico (eds), The Handbook of Historical Economics, Cambridge, MA: Academic Press.

Diamond, J. and J. A. Robinson (eds) (2010), Natural Experiments of History, Cambridge, MA: Harvard University Press.

Domar, E. D. (1970), 'The Causes of Slavery or Serfdom: A Hypothesis', Journal of Economic History, 30(1): 18-32.

Ferrero, M. (1994), 'Bureaucrats versus Red Guards: A Politico-Economic Model of the Stability of Communist Regimes', in R. W. Campbell (ed.), The Postcommunist Economic Transformation: Essays in Honor of Gregory Grossman, Boulder, CO: Westview Press, pp. 281-316.

Fick, C. E. (1990), The Making of Haiti. The Saint Domingue Revolution from Below, Knoxville, TN: The University of Tennessee Press.

Hirschman, A. O. (1970), Exit, Voice, and Loyalty, Cambridge, MA: Harvard University Press.

Hodgson, G. M. (2019), Is Socialism Feasible? Towards an Alternative Future, Cheltenham: Edward Elgar.

Keese, A. (2011), 'Early Limits of Local Decolonization in São Tomé and Príncipe: From Colonial Abuses to Postcolonial Disappointment, 1945-1976', International Journal of African Historical Studies, 44(3): 373-392.

Lacerte, R. K. (1975), 'The First Land Reform in Latin America: The Reforms of Alexandre Pétion, 1809-1814', Inter-American Economic Affairs, 28(4): 77-85.

Lacerte, R. K. (1978), 'The Evolution of Land and Labor in the Haitian Revolution, 1791-1820', The Americas, 34(4): 449-459.

Lacerte, R. K. (1981), 'Xenophobia and Economic Decline: The Haitian Case, 1820-1843', The Americas, 37(4): 499-515.

Lepelletier de Saint-Remy, R. (1846), Saint-Domingue. Etude et Solution Nouvelle de la Question Haïtienne, 2 volumes. Paris: Bertrand.

Leyburn, J. G. (1966), The Haitian People (2nd edn), New Haven and London: Yale University Press.

Lundahl, M. (1979), Peasants and Poverty. A Study of Haiti, New York: St. Martin's Press.

Lundahl, M. (1984), 'Defense and Distribution: Agricultural Policy in Haiti during the Reign of Jean-Jacques Dessalines, 1804-1806', Scandinavian Economic History Review, 32(2): 77-103.

Lundahl, M. (1985a), 'Toussaint L'Ouverture and the war Economy of Saint-Domingue, 1796-1802', Slavery and Abolition, 6(2): $122-138$. 
Lundahl, M. (1985b), 'Government and Inefficiency in the Haitian Economy: The Nineteenth Century Legacy', in M. B. Connolly and J. McDermott (eds), The Economics of the Caribbean Basin, New York: Praeger, pp. 175-218.

Lundahl, M. (2013a), The Political Economy of Disaster: Destitution, Plunder and Earthquake in Haiti, London and New York: Routledge.

Lundahl, M. (2013b), 'The Vision of Toussaint Louverture and the Degeneration of Haitian Politics: An Essay on The Black Jacobins', CLR James Journal, 19(1-2): 332-373.

Mackenzie, C. (1830), Notes on Haiti, Made during a Residence in that Republic (Vol. II), London: Colburn and Bentley.

Matthews, M. (1978), Privilege in the Soviet Union, London: Allen and Unwin.

Naughton, B. (2017), 'Is China Socialist?', Journal of Economic Perspectives, 31(1): 3-24.

Novokmet, F., T. Piketty and G. Zucman (2018), 'From Soviets to Oligarchs: Inequality and Property in Russia 1905-2016', Journal of Economic Inequality, 16(2): 189-223.

Pryor, F. L. (1992), The Red and the Green: The Rise and Fall of Collectivized Agriculture in Marxist Regimes, Princeton: Princeton University Press.

Rozelle, S. and J. F. M. Swinnen (2004), 'Success and Failure of Reform: Insights from the Transition of Agriculture', Journal of Economic Literature, 42(2): 404-456.

Seibert, G. (2016), 'São Tomé and Príncipe 1975-2015: Politics and Economy in a Former Plantation Colony', Estudos Ibero-Americanos, 42(3): 987-1012.

Williams, E. (1984), From Columbus to Castro: The History of the Caribbean 1492-1969, New York: Vintage Books.

Cite this article: Ferrero M (2021). Accidental socialism: a natural experiment in Haiti 1796-1820. Journal of Institutional Economics 17, 393-409. https://doi.org/10.1017/S1744137420000491 